\title{
KONDISI MUSEUM BRAWIJAYA KOTA MALANG \\ SELAMA PANDEMI COVID-19
}

\author{
Amalia Setya Rostanti \\ NIM 200607110021 \\ Jurusan Perpustakaan dan Ilmu Informasi Fakultas Sains dan Teknologi \\ UIN Maulana Malik Ibrahim Malang \\ Jalan Gajayana No. 50 Malang 65144 \\ amaliasetyar@gmail.com
}

\begin{abstract}
Abstrak
Tulisan ini bertujuan untuk menjelaskan bagaimana kondisi dan perawatan koleksi di Museum Brawijaya Kota Malang selama pandemic Covid-19, dimana terdapat koleksi yang harusnya diperbarui tetapi hingga saat ini masih belum diperbarui, dan beberapa perubahan akibat dampak dari pandemic Covid-19 terhadap Museum. Selain untuk pemenuhan tugas Ujian Akhir Semester Genap tahun 2020/2021 mata kuliah Penulisan Ilmiah, penelitian ini juga bertujuan agar harapan meningkatnya jumlah pengunjung Museum Brawijaya Kota Malang di masa Pandemi Covid-19 dan keberlangsungan museum untuk seterusnya dapat terwujudkan. Semoga dengan ditulisnya penelitian dengan judul "Kondisi Museum Brawijaya Malang Selama Pandemi Covid-19" membuat pembaca mengerti kondisi perkembangan Museum Brawijaya Malang baik dari segi perawatan koleksi, perubahan peraturan, fasilitas, dan terhentinya kegiatan rutin yang diadakan oleh Museum Brawijaya, dan juga menjadi motivasi Museum Brawijaya agar terus menjaga eksistensi yang telah ada, semakin bermanfaat dalam dunia militer dan masyarakat sekitar
\end{abstract}

Kata Kunci : Pengembangan Koleksi, Museum Brawijaya Malang, Kondisi Selama Pandemi, Museum 


\section{Pendahuluan}

Menurut Peraturan Pemerintah (PP) No. 19 Tahun 1995, museum adalah lembaga, tempat penyimpanan, perawatan, pengamanan, dan pemanfaatan benda bukti materil hasil budaya manusia, alam dan lingkungannya guna menunjang upaya perlindungan dan pelestarian kekayaan budaya bangsa. (Asmara, 2019). Museum adalah sebuah institusi yang melayani dan mengembangkan sebuah koleksi dan informasi khusus, berharga atau langka yang nyata dan tidak nyata untuk dipelajari, diawetkan, dan digunakan untuk penelitian, yang berfungsi sebagai media penyampaian kepada masyarakat dan pameran untuk tujuan pembelajaran, pendidikan, dan rekreasi. Koleksi museum adalah benda-benda bukti material manusia dan lingkungannya yang berkaitan dengan satu atau berbagai cabang ilmu pengetahuan.

Salah satu museum yang ada di Kota Malang adalah Museum Brawijaya. Museum Brawijaya merupakan museum bertemakan militer yang menyimpan informasi di era perjuangan Indonesia. Museum Brawijaya berperan sebagai tempat rekreasi, pendidikan, penelitian ilmiah, pembinaan wilayah, pembinaan mental juang, pewarisan nilai nilai perjuangan 1945 untuk TNI dan patriotisme untuk umum. Untuk menuju Museum Brawijaya tidaklah sulit. Letaknya di Kota Malang Provinsi Jawa Timur. Tepatnya di Jl. Ijen No. 25 A, Gading Kasri, Kecamatan Klojen, Kota Malang, Provinsi Jawa Timur. (Hafidz)

Suatu sistem atau teknologi terbaru dibutuhkan dalam Museum Brawijaya Kota Malang untuk lebih mempermudah proses pengolahan data koleksi dan informasi di dalamnya. Pembaruan koleksi yang perlu diperbarui setiap tahunnya juga perlu diperhatikan, karena koleksi yang sudah ada hingga saat ini masih belum diperbarui sejak sekitar tahun 2000 . Contoh koleksi tersebut adalah foto dari bangunan-bangunan penting dan umum yang berada di Kota Malang, serta peta kota Malang sejak awal kemerdekaan Indonesia hingga saat ini.

\section{I.Tinjauan Pustaka}

Berbagai penelitian mengenai pengembangan koleksi telah banyak diteliti sebelumnya. Jurnal dan penelitian yang membahas kemiripan teori maupun subjek penelitian dijadikan sebagai acuan dalam penelitian ini. Berikut merupakan penelitian terdahulu yang membahas pengembangan keoleksi museum.

Pertama, penelitian yang dilakukan oleh Arki Auliahadi (2020) dalam jurnal Perpustakaan, Arsip dan Dokumentasi, volume 12. Beliau meneliti tentang bertujuan untuk menjelaskan bagaimana problem yang terjadi dalam manajemen pengembangan koleksi di 
Museum Kerinci. Problem tersebut terkait dengan minimnya koleksi pada Museum Kerinci, sulitnya pihak pengelola museum untuk mendapatkan koleksi yang menjadi jantung bagi sebuah museum. Hasil penelitian menunjukkan bahwa Museum Kerinci dibangun untuk mempertahankan nilai dan budaya masyarakat Kerinci, baik berupa Benda Cagar Budaya (BCB) maupun adat dan tradisi.

Kedua, penelitian yang dilakukan oleh Alifiani Kurnia Risdianti dan Eko Satriya Hermawan (2021) dalam jurnal Pendidikan sejarah, volume 10. Beliau meneliti tentang perkembangan Museum Brawijaya Malang sepanjang tahun 1968 hingga 2018. Eksistensi perkembangan Museum Brawijaya ialah nyata adanya yang mana dibuktikan dengan arus perkembangan masuknya koleksi ke dalam Museum Brawijaya pun juga dengan adanya pergantian pelaksana pengelola museum. Lalu upaya edukasi yang dilakukan yaitu melalui dua kegiatan utama yakni melalui pameran tetap dan pameran keliling dengan fokus utama pendidikan yaitu untuk meningkatkan rasa nasionalisme dan semangat patriotik bagi masyarakat luas pada umumnya dan prajurit ABRI pada khususnya.

Dari kedua peneletian tersebut dapat diambil persamaan dengan penelitian ini adalah pengembangan koleksi yang perlu diperbarui dan strategi Museum Brawijaya Kota Malang dalam meningkatkan upaya edukasi terhadap pengunjung dengan melakukan pameran. Namun perbedaannya dengan tulisan ini yaitu mebahas tentang pengembangan koleksi dan kondisi Museum Brawijaya selama Pandemi Covid-19, dimana strategi yang sudah ada tidak efektif kembali.

\section{II.Metode Penelitian}

Penelitian ini dilaksanakan pada tanggal 1 Maret 2021 di Museum Brawijaya Kota Malang yang bertempat di Jl. Ijen No. 25 A, Gading Kasri, Kecamatan Klojen, Kota Malang, Provinsi Jawa Timur. Penelitian ini dilaksanakan dengan tujuan untuk memenuhi tugas Ujian Akhir Semester Genap tahun 2020/2021 mata kuliah Penulisan Ilmiah Jurusan Perpustakaan dan Ilmu Informasi, Fakultas Sains dan Teknologi, UIN Maulana Malik Ibrahim Malang.

Jenis penelitian ini adalah penelitian kualitatif deskriptif. Metode kualitatif deskriptif dapat diartikan sebagai prosedur pemecahan masalah yang diselidiki dengan menggambarkan keadaan subjek atau objek dalam penelitian dapat berupa orang, lembaga, masyarakat dan yang lainnya yang pada saat sekarang berdasarkan fakta-fakta yang tampak atau apa adanya 
Sugiyono (2012) menjelaskan bahwa penelitian deskriptif yaitu, penelitian yang dilakukan untuk mengetahui nilai variabel mandiri, baik satu variabel atau lebih (independen) tanpa membuat perbandingan, atau menghubungkan dengan variabel yang lain. Menurut Sudjana dan Ibrahim (2004) penelitian deskriptif adalah "penelitian yang berusaha mendeskripsikan suatu gejala, peristiwa, kejadian yang terjadi pada saat sekarang”.

Berdasarkan pengertian tersebut dapat disimpulkan bahwa penelitian kualitatif deskriptif dilakukan dengan cara mencari informasi berkaitan dengan gejala yang ada, dijelaskan dengan jelas tujuan yang akan diraih, merencanakan bagaimana melakukan pendekatannya, dan mengumpulkan berbagai macam data sebagai bahan untuk membuat laporan. (Jayusman \& Shavab, 2020).

Subyek penelitian ini adalah subyek kepustakawanan karena penelitian ini dilaksanakan di sebuah Museum, lebih tepatnya Museum Brawijaya Kota Malang. Penelitian ini termasuk dalam kajian dokumen, akses dan Pemanfaatan Informasi, dengan menggunakan teori penemuan informasi dalam situasi sehari-hari. Perilaku penemuan informasi terjadi karena adanya kebutuhan informasi yang dirasakan seseorang. Faktor-faktor yang mempengaruhi penemuan informasi adalah pencari informasi, keadaan/masalah informasi, bidang pengetahuan, sistem penelusuran dan hasil yang didapat.

Teknik pengumpulan data untuk mendapatkan data yang valid dan akurat, dilakukan beberapa hal yaitu, observasi, wawancara dan dokumentasi. Dalam penelitian ini menggunakan teknik obsevasi nonpartisan, dimana peneliti tidak terlibat dan hanya sebagai pengamat independen. Peneliti mengamati kegiatan pelayanan terhadap pengunjung museum. Usaha pendokumentasian yang dilakukan dalam penelitian ini untuk mendapatkan data yang telah diolah baik dalam arsip tertulis maupun arsip lainnya.

\section{Pembahasan dan Hasil Penelitian}

\section{Sekilas Tentang Museum Brawijaya}

Museum Brawijaya Malang merupakan sebuah museum yang berisi peninggalan sejarah pada masa sebelum kemerdekaan, perang kemerdekaan, serta periode setelah kemerdekaan. Selain itu, koleksi museum tersebut antara lain berupa senjata tradisional hingga modern, lukisan, koleksi senjata-senjata, tank, kendaraan amphibi, serta berbagai bendera dan lambang-lambang kesatuan angkatan darat, memberikan gambaran tentang beratnya masa perjuangan penduduk Malang melawan penjajah. Museum ini didirikan dengan tujuan sebagai media pendidikan, tempat wisata 
sejarah, penelitian ilmiah, di mana masyarakat bisa mengenal dan mengenang sejarah perjuangan bangsa Indonesia, khususnya rakyat Jawa Timur sejak tahun 1945, sehingga dapat menjadi tempat pembinaan mental kejuangan dan pewarisan "Nilai-nilai 1945". (Tjayawulan \& Adityayoga, 2019).

Museum Brawijaya menyimpan berbagai koleksi yang berhubungan dengan benda-benda yang terkait dengan sejarah kemiliteran Indonesia, mulai zaman perang kemerdekaan, perebutan kembali Irian Barat, penumpasan komunis hingga Operasi Seroja di Timor Timur. Secara keseluruhan, museum ini memiliki beberapa lokasi atau ruang untuk menyimpan dan meletakkan koleksi. Pembagian lokasi/ruangan koleksi tersebut diatur sesuai dengan alur pengunjung, sebagai berikut:

1. Halaman Depan museum dinamakan Agne Yastra Loka atau Taman Senjata. Di sini dipamerkan tank, senjata penangkis Serangan Udara, Meriam (Cannon) 3,5 Inch yang diberi nama Si Buang dan Tank AMP-TRACK.

2. Lobi Entrance, memamerkan relief (lukisan timbul di dinding) dan perangkat lambanglambang kodam (Badge).

3. Ruang Koleksi 1, memamerkan koleksi dari tahun 1945 hingga 1949.

4. Ruang Koleksi 2, memamerkan koleksi mulai tahun 1950 hingga 1976.

5. Halaman Tengah

6. Perpustakaan

\section{Museum Brawijaya di Masa Pandemi Covid-19}

Pada masa pandemi covid-19 ini kita semua harus mengikuti semua aturan dan protokol kesehatan yang telah di anjurkan pemerintah untuk mengatasi dan mencegah penyebaran covid-19. Hampir semua tempat wisata terdampak pandemic ini, termasuk Museum Brawijaya sebagai tempat wisata edukatif di Kota Malang. M. A. Tabiin menjelaskan bahwa

"Sekitar 90\% Museum mengalami kemrosotan pengunjung. Dalam satu bulan rata-rata pengunjung hanya 90-100 pengunjung, yang biasanya mencapai 1000 pengunjung. "

Mayoritas pengunjung Museum Brawijaya adalah pelajar, dimana cukup berpengaruh besar dalam intensitas pengunjung museum. Karena di masa pandemic Covid-19 ini, pemerintah memeberikan kebijakan bahwa seluruh pelajar di Indonesia diharuskan untuk melakukan pembelajaran secara daring dan untuk tetap berdiam diri dirumah saja.

Pandemi Covid-19 juga memberikan perubahan peraturan yang di adakan di Museum Brawijaya. Seperti pengunjung dan pihak museum wajib mengikuti protocol 
kesehatan yang di anjurkan oleh pemerintah. Dan terdapat beberapa fasilitas tambahan juga disediakan oleh Museum Brawijaya, seperti tempat cuci tangan, sabun, dan hand sanitizer. Tentu saja pihak Museum Brawijaya mewajibkan untuk seluruh pengunjung dan karyawan menggunakan masker, untuk pencegahan penularan virus Covid-19.

Penyelenggaraan pameran yang diadakan rutin mengikuti agenda dari Dinas Kebudayaan dan Pariwisata Provinsi Jawa Timur setiap satu tahun sekali. Museum Brawijaya aktif mengikuti pameran tersebut sebelum pandemic Covid-19. Seperti yang dijelaskan oleh M. A. Tabiin bahwa

"Kalau sebelum pandemic, dulu kita sudah rutin mengikuti agenda dari Disbudpar Provinsi Jawa Timur setahun sekali. Pameran ini diselenggarakan berbeda kota setiap tahunnya. Dan kita aktif dalam mengikuti pameran itu."

Namun selama pandemic Covid-19 ini Museum Brawija belum mengikuti dan menyelenggaran pameran lagi, dikarenakan kebijakan pemerintah yang tidak memperbolehkan untuk mengadakan acara yang menimbulkan kerumunan.

\section{Perawatan Koleksi Museum Brawijaya}

Museum diartikan sebagai sebuah gedung yang digunakan sebagai tempat untuk memamerkan benda-benda yang patut mendapat perhatian umum, seperti peninggalan sejarah, seni, dan ilmu. (Heru, dkk.). Koleksi museum merupakan nyawa pada setiap museum. Koleksi menunjukkan titik utama kesinambungan antara identitas museum dengan isi didalamnya. Seperti halnya Museum Brawijaya, koleksi Museum Brawijaya merefleksikan bahwa hadirnya museum ini guna mengenang pemberontakan dan pertempuran yang ada di Jawa Timur pada khususnya dan Indonesia pada umumnya.

Koleksi di Museum Brawijaya tidak hanya berisikan senjata, dan alat-alat perang yang digunakan oleh pejuang saja. Namun, banyak juga koleksi-koleksi lainnya seperti lembaran dan kepingan uang zaman dahulu hingga saat ini, benda-benda bersejarah seperti perabotan rumah pejabat Kota Malang, baju dan seragam milik TNI, alat transpostasi yang digunakan oleh para pejuang, potret Kota Malang dan bangunanbangunan yang melegenda di Kota Malang, mesin-mesin yang digunakan pada zaman penjajahan, dan lain-lain.

Koleksi di Museum Brawijaya terlihat terawat dengan baik. Namun terdapat beberapa koleksi yang seharusnya bisa diperbarui, tetapi tidak diperbarui hingga saat ini. Contohnya seperti peta Kota Malang dan potret bangunan-bangunan yang melegenda di Kota Malang. Seiring berjalannya waktu, bangunan tersebut telah di renovasi dan di perbarui, namun koleksi di museum masih tetap dengan potret 
bangunan yang lama. M. A. Tabiin selaku pengelola Museum Brawijaya menjelaskan bahwa

"Benda koleksi memang dibiarkan apa adanya, kecuali kalau ada kerusakan parah akan dilakukan perawatan dan observasi. Kalau kotor, cukup dibersihkan saja. Hal tersebut bertujuan untuk menunjukkan keasliannya."

Koleksi di Museum Brawijaya memang dibiarkan apa adanya untuk menunjukkan keasliannya. Jika ada penyumbang yang akan menyumbangkan koleksi berupa peta maupun potret foto, maka koleksi tersebut akan diperbarui. Apalagi di masa pandemic Covid-19 seperti saat ini, kemungkinan penyumbang tidak ada cukup besar. Dikarenakan pihak Museum akan lebih memfokuskan untuk mematuhi peraturan Pemerintah tentang kebijakan Covid-19.

\section{Penutup}

\section{Kesimpulan}

Museum Brawijaya Malang merupakan sebuah museum yang berisi peninggalan sejarah pada masa sebelum kemerdekaan, perang kemerdekaan, serta periode setelah kemerdekaan. Pandemi Covid-19 juga memberikan perubahan peraturan yang di adakan di Museum Brawijaya. Seperti pengunjung dan pihak museum wajib mengikuti protocol kesehatan yang di anjurkan oleh pemerintah. Dan terdapat beberapa fasilitas tambahan juga disediakan oleh Museum Brawijaya. Tidak hanya peraturan dan fasilitas, pandemic menyebabkan operasi museum dalam mengadakan pameran rutin menjadi terhenti sementara hingga pemerintah mengeluarkan kebijakan baru, utnutk bisa mengadakan pameran.

Koleksi yang terdapat dalam Museum Brawijaya tidak terlalu banyak terdampak pandemic covid-19. Hanya saja terhambat oleh penyumbang yang belum bisa menyumbang koleksi di Museum Brawijaya dikarenakan Covid-19. Perawatan terhadap koleksi juga tetap dilakukan oleh petugas museum meskipun di masa pandemic Covid-19.

\section{Saran}

Semoga dengan ditulisnya penelitian dengan judul "Kondisi Museum Brawijaya Malang Selama Pandemi Covid-19" membuat pembaca mengerti kondisi perkembangan Museum Brawijaya Malang baik dari segi perawatan koleksi, perubahan peraturan, fasilitas, dan terhentinya kegiatan rutin yang diadakan oleh Museum Brawijaya, dan juga menjadi motivasi Museum Brawijaya agar terus menjaga eksistensi yang telah ada, semakin bermanfaat 
dalam dunia militer dan masyarakat sekitar pada khususnya dan masyarakat luas pada umumnya, agar selalu tetap menjaga segala bentuk arsip penting terkait Museum Brawijaya untuk memudahkan segala bentuk penelitian ilmiah yang akan dilakukan kelak di masa yang akan datang dan museum harus selalu melakukan kegiatan sosialisasi yang mana menjaring kaum pemuda guna tetap berkunjung dan melestraikan museum agar tidak menjadi sebuah monumen yang mati

\section{Daftar Pustaka}

Auliahadi, A. (2020). Problem Manajemen Pengembangan koleksi di Museum Kerinci. Jurnal Perpustakaan, Arsip dan Dokumentasi, 12, (1), 1.

Alifiani, K. R. \& Eko, S. H. (2021). Museum Brawijaya Malang Tahun 1968-2018. Jurnal Pendidikan Sejarah, 10, (2), 10.

Aly, M. N. (2018). Strategi Pengembangan Even Di Museum Untuk Meningkatankan Kunjungan Wisatawan Ke Museum R.A Kartini Rembang. Jurnal Media Wisata, 16, (1), 1.

Arikunto, Suharsimi. (2013). Prosedur Penelitian Suatu Pendekatan Praktik. Jakarta: PT. Rineka Cipta.

Asmara, D. (2019). Peran Museum Dalam Pembelajaran Sejarah. Jurnal Pendidikan Sejarah dan Riset Sosial Humaniora, 2, (1), 14.

https://sejarahlengkap.com/bangunan/sejarah-museum-brawijaya (Diakses 23 Maret 2021)

Jayusman, I., \& Shavab, O. A. K., (2020). Studi Deskriptif Kuantitatif Tentang Aktivitas

Belajar Mahasiswa Dengan Menggunakan Media Pembelajaran Edmodo Dalam Pembelajaran Sejarah. Jurnal Artefak, 7, (1), 15.

Sugiyono. (2012). Metode Penelitian Kuantitatif, Kualitatif, dan R\&D. Bandung: Alfabet.

Tjajawulan, I., Adityayoga. (2019). Penyajian Koleksi Museum Sejarah dan Budaya Kota Malang. Jurnal Senirupa Warna, 7, (2), 7. 
